Utah State University

DigitalCommons@USU

$5-1942$

\title{
The Effect of Some Environmental Influences in Bulk Hybridization of Grass
}

John W. Clark

Utah State University

Follow this and additional works at: https://digitalcommons.usu.edu/etd

Part of the Agriculture Commons

\section{Recommended Citation}

Clark, John W., "The Effect of Some Environmental Influences in Bulk Hybridization of Grass" (1942). All Graduate Theses and Dissertations. 3925.

https://digitalcommons.usu.edu/etd/3925

This Thesis is brought to you for free and open access by the Graduate Studies at DigitalCommons@USU. It has been accepted for inclusion in All Graduate Theses and Dissertations by an authorized administrator of DigitalCommons@USU. For more information, please contact digitalcommons@usu.edu.

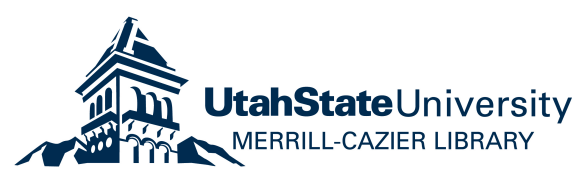




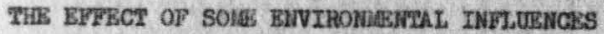

II BULK HYBRTDIZATION OF ORASS

\title{
by
}

John W. Clark

A thesis submitted in partial furfiziment of the requirements for the degree of

\author{
Haster of Saience
}

in the

School of Agricul ture

Utah State Agricultural College

1942 


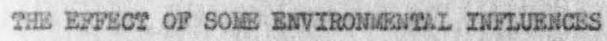

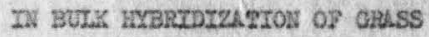

\section{by}

John w. Clark

A thesis subnitted in partial frulfylment of the requirezents for the degree of

Laster of Scleace

in the

School of Agriculture

Wtah State Agrloultural Collage

1942

Approved: 


\section{ACKNOWLEDORIBSNT}

The study herein reported was conducted while the writer held a joint fellowship with the Dtah Agmicultural Experiment Station, and the Utah State Agmicultural college. Plant material and equipment was furnished by the U. S. Dept. of Agriculture, Bureau of Plant Industry, Division of Forage Crops and Diseases. The writex vishes to express his appreclation and thanks to Dr. Vesley Keller, fron whon numerous suggestions and eriticians have been recelved, for his advice and help in proparation of this mamuscript. 
Introduction ................. I

Revlew of literature ............... 5

Experinental methods ............... 5

Bquipaent

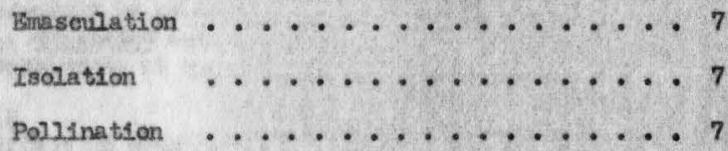

Experinental results

Denonstration of differentias and comparisan of several methods of bulk pollination... . 8

Successive Daily exposures. .......... II

Daily ternerature fluctuations inside and outside Iso2.ation bag. .......... I3

Effect of time of treatment on seed production. . 15

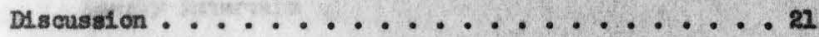
sumary .................... 24 Ifterature cited ................ 26 
Table 2

Seeds produced by selfing and by controlled hybridization procedures by relatively self-fertsle genotypes of Bromus inermis, Agropyron cristatum, and A. smithis following hot water emasculation treatients at specified teraperatures.

Table 2

Seads produced by selfing and by intermittant and continuous exposure by relatively self-fertile genotypes of $\mathrm{B}$. Inerais, A. crlstatum and A. Snithil following hot water enasculation treatnents at specilled teraperatures.

Table 5

Bffect on seed production of different mubers of successive dasly exposures of one hour during anthasis in relation to seed production by selfing and from contimuously exposed (not bagged) splkes of bluester wheatgrass (not emasculated).

Table 4

Bffect of time of treatant on seed production by flve methods of crass polizination in a seif-sterlie genotype of smooth bromegrass.

Table 5

Seeds produced per 100 spikelets of a self-sterlie genotype of smooth bronegrass. The plants were enasculated at howrly intervals throughout the day.

Table 6

Seeds produced per 100 splkelets in a self-sterlle genotype of smooth bromegrass by cross pollination following enascuIation at hourly Intervals throughout the day.

\section{Rgure 1}

Air terperatures inside (dotted lines) and outside the isolation bags (Bolid lines) for Agropyron orlstatum and Bromus inerris for a perlod of six days during anthesis. 


\section{INTropucrion}

For decades man has been interested in selection and hybridiastion of crop plaats, but it has not boen until in comparatively recent years that anything of importance has been done toward the iraprovercent of perennial forage grasses. Replies to questionnaries on grass breeding subatted to varicus agricultural institutions in 2936 rovealed the fact that selection for ingrovenent was then under way with a large number of grasses. Lirat ted activities in this flold have been In progress for 16 years or more, but organizad and intensive grass breeding activities, for the most part, have been in augurated only within the last ten years.

Wany Laproved strains of grasses have been developed by selective breeding in forelgn countries but very fen of these have showa outstanding value in the United States. In fact, they are generally inferior.

There is a great deal of interest at the present time in this country in the fleld of grass breeding, but the amaliness of the floral parts of some grasses makes the work of controlled hybridization tedious and slor. I simple, Inexpensive, accurate method for bulk hybridization would be useful and would speed up the work. The study herein reported was designed to throw further light on the possibility of bulk hybridization. The 
technic involves inuersion of inflorescences in water heated to specific temperatures to effect enactivation of pollen. As a necessary corollary, the desired pollen is then applied by any of severul methods.

Several investigators, mentioned below, have shown that controlled heat treatuents ajplied to Inflorescenses near the time of anthesis are effective in seriousiy redueing the viability of pollen without having a similar effect on the ferale ganetophyte. However, none has deaonstrated good ferale fertil1ty folloving complete male sterilization. It has become apparent that influences of the plants' environment other than the heat of the enssculation treatment must be taken into consideration. In the present atudy, which was conducted on three Important forage grasses, swooth bromegrass (Bromus inerris), crested wheatgrass (Agropyron gristatun), and bluesten whestgrass (Agropyron gmithif), the general findings of earlier investigators are substantiated and in addition evidence is presented to show (I) the sterilising effect of the 1solation bag and (2) the existence of a daily cycle in the efriciency of ensisculation of treatinents at critical teraperatures. 


\section{RLVIEU OP TITSRATUES}

The 11terature on bulk emasculation and bulk pollination has been adequately reviewed by Doningo (2) and wilz be mentioned only brieny here. Stephens and Quinby (4) reported the effectiveneas of hot water in the enasculat on of sorghum. Jodon (5) reported that both hot and cold water wore effective in the enascuIation of rice. Suneaon (5) denicnstrated that wheat was partially easasculated by prolonged low air tenperatures. Bulk pollen tranefer has long been useful In corn breeding, Febber (6), Coulter (1). It has also been effective in obtaining hybrids among cereals, as reported by several investlgators. Perhaps the most oritical and extensive study reported in the literature, covering both bulk emasculation and pollination, is that of Domingo (2). He atterpted bulk enasculation of amooth bromegrass (Bromis 1nernis) by the use of hot water, hot air, and cold air. The plants used were selected on the basis of their relatively high self-fertility. The success of emasculation was measured by the difference in seed set of treated panicles which were selfed and those wilch were exposed to atnospheric pollen, Hot water treatments were aade for 5 minutes at one-degree Intervals from 37-51 degrees centigrade by fmersing the panicles in water contained in a one-gallon thernos jug. Several treatrients prevented the foration of selfod seed yet perritted the fornation of seeds on sindlariy treated panicles which were exposed to 
a thospherle polien, but the results were not altogether consistent. The sost effective teaperatures appeared to be $46^{\circ}$ and $47^{\circ} \mathrm{C}$. Hot air was found to be effective in enasculating smooth bronegrass but the results were less conslstent than with hot vater. Several. methods of bulk pollination tried by Doningo all yielded some hybrid seed, However, in a preliminary study conducted on the bulk polizination of emasculated pantcles, 11 ttle seed was produced. 
Bulk erasculation and bulk pollination was atteripted on three spectes of grasses by treating the inflorescences with hot water at specifio temperatures 2 to 8 days prior to anthesis. During anthesis, polien was transforred from male to fanale plsnts by several different methods listed below. To insure against damage to the plants when inserting the inflorescences Into the thermos Jug, a large handkerchief was wrapped firmily around the group of stems to be treated, starting at the base and extending upward. Plants were selected for trestment which had previously produced considerable selfed seed when lsolated in kraft begs. The auccess of the technic was evaluated by a difference in the amount of seed produced following hot water treatraents and specifle pollination practices relative to seed produced by controls. Several inflorescences were treated simultaneousiy and bagged immediately or left exposed, accordIng to the methods which follow:

\section{Selfod.}

2. Bagged, but having strained pollen introduced into the bag on five days favorabie for atmospheric pollen.

3. Bagged, but having severed pollen bearing inflorescences introduced into the bag on five successive pollen shedding days.

4. Bagged, with severed pollen bearing inflorescences standing in water and inserted in the beg at the beginning of anthesis. 
5. Bagged, but in association with intact inflorescences of another genotype (untreated) which provided pollen.

6. Bagged, but exposed I hour on each of flve successive days favorable for natural pollination.

7. Bagged without treatment, then being subjected to various muabers of dafly exposures at hourly intervals on days fevorable for atzospheric pollen.

8. Bxposed to natural pollination following emasculation trea tnent.

9. Three untreated and unbagged inflorescences from ench of the several genotypes were harvested and seed counts obtained. This gave a cheek on the efficiency of the various methods of controlled pollination.

or the three grasses experimented with, methods 4 and 7 were not applled to smooth bromegrass, methods 5,6 and 7 were not applied to crested wheatgrass, and methods 2 and 5 were not applied to bluesten wheatgrass.

Treatzents which effected enasculation without appreciable infury to the fenale organs were detected by lack of seed set on the selfed inflorescences, accompanied by formation of seed on those which received the same treatrent sirul taneousiy but rewained exposed to natural pollination. The pollen transfer methods were used to produce controlled hybrids on the inflorescences that had been exasculated. The also served as a check on the viability of the stigmas. Inflorescences not treated and unbagged gave a measure of the effectiveness of atmospheric pollen, and apparent injury to the stigna by treatment. 
Equipment for emssculation. - Dabsculation equiprent consisted of a wide-mouth thernos jug, an accurate therrometer, and a wre 10op for stirring the water in the thernos Jug. A one-bumer gasoline stove was very useful for heating water in the fleld, and 1t, together with a rater bag filled with cold water, provided a means of making temperature changes rapidiy.

Equiprent for 1solation. - Isolation of apikes or panieles was made possible by the use of $3^{\prime \prime} \times 26^{\prime \prime}$ kraft paper bags. The bags were supported by a number 9 galvanized wire that was forced Into the ground at the bese of the plant. A 1 8/4" loop in the upper end of the rire prevented the bag from collapsing and thus Injuring the infloresence.

Equipaent for pollination. - A large light reflector was used to gather pollen for the isolation bags that were to recelive strained pollen. The pollen was separated from the anthers by a fine mesh screen. A small metal contalner was used to carry the pollen from one genotype to another. This container vas wrapped with cloth and the cloth was soaked in water. Bvaporation cooled the container and helped prevent the pollen from forming aggregates. A teaspoon was used to transfer the pollen from the metal container into the 1solation bags. In one of the several other bulk pollination nethods employed, stens were severed near their bases and placed in water contained in one-quart mason jart, in order to extend the period during which their inflorescences 
would shed viable pollen. None of the other methods of pollination required equipment.

\section{BXPERTMENTAL RESULTS}

\section{Demonstration of differential and compariaon of several}

nethods of bulk pollination. - A defferential in the thermal death point of male and ferale gametophytes is denonstrated if it can be proved that, following an emasculation treatment self pollen Is nonfunctional while untreated, Introduced pollen leads to seed formation. This relationship is most easily denonstrated with relatively self fertile genotypes. Tables 1 and 2 contain data supporting the differential for the respective grasses involved. The nost appropriate critical temperature appears to be $47^{\circ} \mathrm{C}$. However, good results were also secured at $48^{\circ} \mathrm{C}$. on bluestera wheatgrass. It is shown that 3 relatively self-fertile genotypes of E. Inerais (mean self-fertsility under bags per 200 spikelets 106 seeds (table 1)), were restricted to .I seeds per 100 splkelets when treated at $47^{\circ} \mathrm{C}$. for 5 minutes and then begged. These sare 3 genotypes, on panicles treated simnitaneously with those selfed, ylelded 10.5 seeds per 100 spikelets when untreated pollen was introduced during anthesis, and 26.8 seeds per 100 splikelets were obtained when the 1solation bag was renoved for 1 hour during anthesis on 5 days favoreble for polination. 
Table 1. Seeds produced by selfing and by controlled hybridization procedures by relatively self-fertile geno-

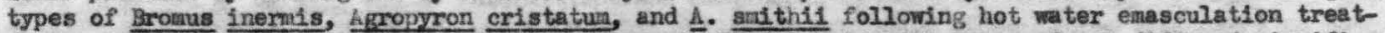
nents at specified termeratures. None of the controlled hybridization procedures differed signiflcantily in seed production. $47^{\circ} \mathrm{C}$. appears to be the most suitable enasculation temperature. Fach cell in the table is based on 2150 to 4200 spikelets (B. Inerais); 11 to 20 spikes (A. cristatum); 26 to 43 spikes (A. sinthis).

\begin{tabular}{|c|c|c|c|c|c|c|c|c|c|}
\hline \multirow{2}{*}{$\begin{array}{l}\text {-ininute } \\
\text { treatment } \\
\text { temperature C. }\end{array}$} & \multicolumn{2}{|c|}{ (gesins of $8 \frac{\text { inernis: }}{\text { genotypes) }}$} & \multicolumn{4}{|c|}{ Agropyron $\frac{\text { eristatuin }}{\text { (neans of } 4}$} & \multicolumn{3}{|c|}{$\begin{array}{l}\text { Agropyron smithil } \\
\text { (neans of } 9 \text { genotypes) }\end{array}$} \\
\hline & Selfing & 7 aㅏ옹 & Selfing & 2 & 8 & $\sqrt{4}$ & Selfing & 8 & 4 \\
\hline 48 & & & 0 & 2.3 & 4.6 & 0 & 1.9 & 17.6 & 12.0 \\
\hline 47 & .1 & 10.8 & .6 & 23.2 & 6.0 & 12.8 & 2.2 & 11.5 & 20.0 \\
\hline 46 & 8.2 & 59.8 & 4.8 & $17 \cdot 2$ & 28.0 & 16.0 & 5.5 & 25.0 & 23.6 \\
\hline 45 & 17.5 & 36.5 & 51.6 & 41.2 & 15.6 & 14.8 & 14.0 & 18.8 & 19.8 \\
\hline 44 & & & 20.8 & 18.0 & 42.4 & 35.6 & 26.2 & 30.9 & 24.9 \\
\hline 48 & & & 14.0 & 33.6 & 34.8 & 28.0 & 24.9 & 30.0 & 64.0 \\
\hline Untreated & 106.0 & 99.0 & 51.6 & & & & 30.5 & & \\
\hline Mean of treated. & & & & 22.6 & 21.9 & 17.9 & & 22.8 & 27.4 \\
\hline
\end{tabular}

* Seeds per 100 spikilets. A. cxistatum and A. saithil beised on seeds per 4 spikes.

* Description of hybridization procedure.

1 - Plants were grom in pairs, 2 genotypes bagged together, the one providing pollen was untreated.

2 - Freshly strained pollen from a different genotype was introduced into bag on 5 suceessive pollen shedding days.

5 - 2 severed pollen bearing spikes suspended in top of isolation bag on each of 5 successive pollen shedding days.

4 - 2 severed pollen bearing spikes standing in water, at beginning of anthesis. 
Table 2. Seeds produced by selfing and by internittant and continuous exposure by relatively self-fextile genotypes of B. Inerais, A. erlstatum and $\mathrm{A}$. salthil follouing hot water evasculation treatients at specified temperatures. Intera ittant exposure consisted of reaving the isolation beg for 1 hour during anthesis on each of 5 pollen shedding days. Bach cell in the table is based on 2150 to 4160 spikelets, (B. Ineraus); 11 to 20 spikes (A. cristatum); 26 to 43 spikes (A. smithil).

\begin{tabular}{|c|c|c|c|c|c|c|c|c|}
\hline \multirow[b]{2}{*}{$\begin{array}{l}\text { Treatinent } \\
\text { tempera ture } \mathrm{C} .\end{array}$} & \multicolumn{3}{|c|}{ (imeans of $\frac{\text { Bnerrisp }}{8 \text { genotypes) }}$} & \multicolumn{2}{|c|}{ (yeans of 4 genotypes) } & \multicolumn{3}{|c|}{$\begin{array}{l}\text { E. } \frac{\text { snithili }}{9 \text { genotypes) }} \\
\text { (zieans of }\end{array}$} \\
\hline & Selfing & $\begin{array}{l}\text { Exposed } 1 \mathrm{hr} \text {. } \\
\text { on } 5 \text { days }\end{array}$ & $\begin{array}{l}\text { Contimuously } \\
\text { exposed } \\
\text { (unbagred) }\end{array}$ & Serfiag & $\begin{array}{l}\text { Contimuousty } \\
\text { exposed } \\
\text { (unbagged) }\end{array}$ & Selfing & $\begin{array}{l}\text { Exposed } \\
1 \text { hr. or } \\
5 \text { days }\end{array}$ & $\begin{array}{l}\text { Continu- } \\
\text { ously ex } \\
\text { n posed. } \\
\text { (unbagg }\end{array}$ \\
\hline 48 & & & & 0 & 38.4 & 1.9 & 28.4 & 79.0 \\
\hline 47 & 2 & 26.8 & 86.6 & .6 & 92.6 & 2.2 & 28.7 & 92.5 \\
\hline 46 & 8.2 & 56.3 & 2.45 .0 & 4.8 & 282.8 & 5.5 & 42.0 & 99.4 \\
\hline 45 & 17.3 & 88.0 & 206.0 & 31.6 & 236.0 & 14.0 & 35.6 & 119.9 \\
\hline 44 & & & & 20.8 & 126.8 & 26.2 & 39.0 & 150.6 \\
\hline 48 & & & & 14.0 & 175.2 & 24.9 & 62.4 & 160.2 \\
\hline Untreated & 106.0 & & 288.0 & 52.6 & 126,8 & 30.5 & & 140.9 \\
\hline Mean of treated & & & & & 216,0 & & 39.0 & 116.8 \\
\hline
\end{tabular}

* Seeds per 100 spikelets: L. cristatur and A. smithil based on seeds per 4 spikes. 
A sinilar interpretation is appropriate to $\mathrm{A}$. eristatum and A. satints. In no case do the several nethods of controlled hybridization differ significantly in effectiveness, but exposure to randon natural pollination gives increases in seed over controlled hybridization as shown by table 2 ; whereas treated inflorescenses, which are not bagged at all, invariably ylelded several times more seed than was obtained from bagged inflorescences (table 2). Two important questions are here raised, (1) Are any methods of pollination of bagged inflorescences adequato (including 1-hour exposures on 5 successive pollen shedding days)? and if so, (2) are the reduced seed yields under begs an fndication that the bag 1 tself has an effect which is additive to that of the enasculation temperature treatment? The Iinited inforation at hand does not allow a satisfactory answer.

Successive daily exposures. - In order to detemine if possible, the adequacy for cross fertilization of 5 dally exposures, as reported in table 2 , an experiment was set up with bluesten wheatgrass in which different groups of untreated but bagged spikes were exposed on 1 to 4 successive pollen shedding days. The plants were growing in proximity to many other plants which assured a good pollen supply. Nine genotypes mere employed and each contributed one bag of 4 spikes to each exposure treetment. The data are sumarized in table 3. Exaulnation of the table reveals that four deily exposures yielded only half as 
Table 3. Effect on seed production of different numbers of successive daily exposures of one hour during anthesis in relation to seed production by selfing and from continuously exposed (not bagzed) spikes of bluestem wheatgrass (not emasculated).

Number of successive daily exposures during anthesis

\begin{tabular}{llllll}
\hline $\begin{array}{l}\text { None } \\
\text { (selfed) }\end{array}$ & One & Tro & Three & Sour & $\begin{array}{c}\text { Continuously } \\
\text { exposed }\end{array}$ \\
\hline 30.5 & 49.7 & 47.5 & 40.6 & 73.4 & 140.9 \\
\hline
\end{tabular}


much seed as continuous exposure (not bagsed). One to three exposures yielded little more seed than selfing but, although pollen was shed on each day that bags vere renoved, the atmospherle temerature during the course of this study was considerably below noral and the data have probably been influenced accordingly.

Daily teagerature fluctuations ingide and outside the isolation bag during anthesis. - In recognition of the possibility that high teaperatures developed Inside the isolation bags, readings were taken simultaneously inside and outside the bags 4 or 5 times daizy.

A small hole was made in the top of each isolation bag Just large enough for a thermoneter to be inserted. Then the temperature was not being taken a small piece of adhesive tape covered the opening. Two sccurate thermometers were used, one Instde the bag, and the other in the shade of the bag for recording the atmospherie temperature. When temperature readings were being taken the themiometers were left in place long enough to fully adjust to the terperature encountered. The data are presented in IIgure 1. Bach point in this IIgure is the mean of nine readings, each taken in a different bag.

It is apparent that during the daytime, tetaperatures withIn the bags ranged approximately two degrees above those taken simul taneousiy in the shade of the bags. It is considered highly 


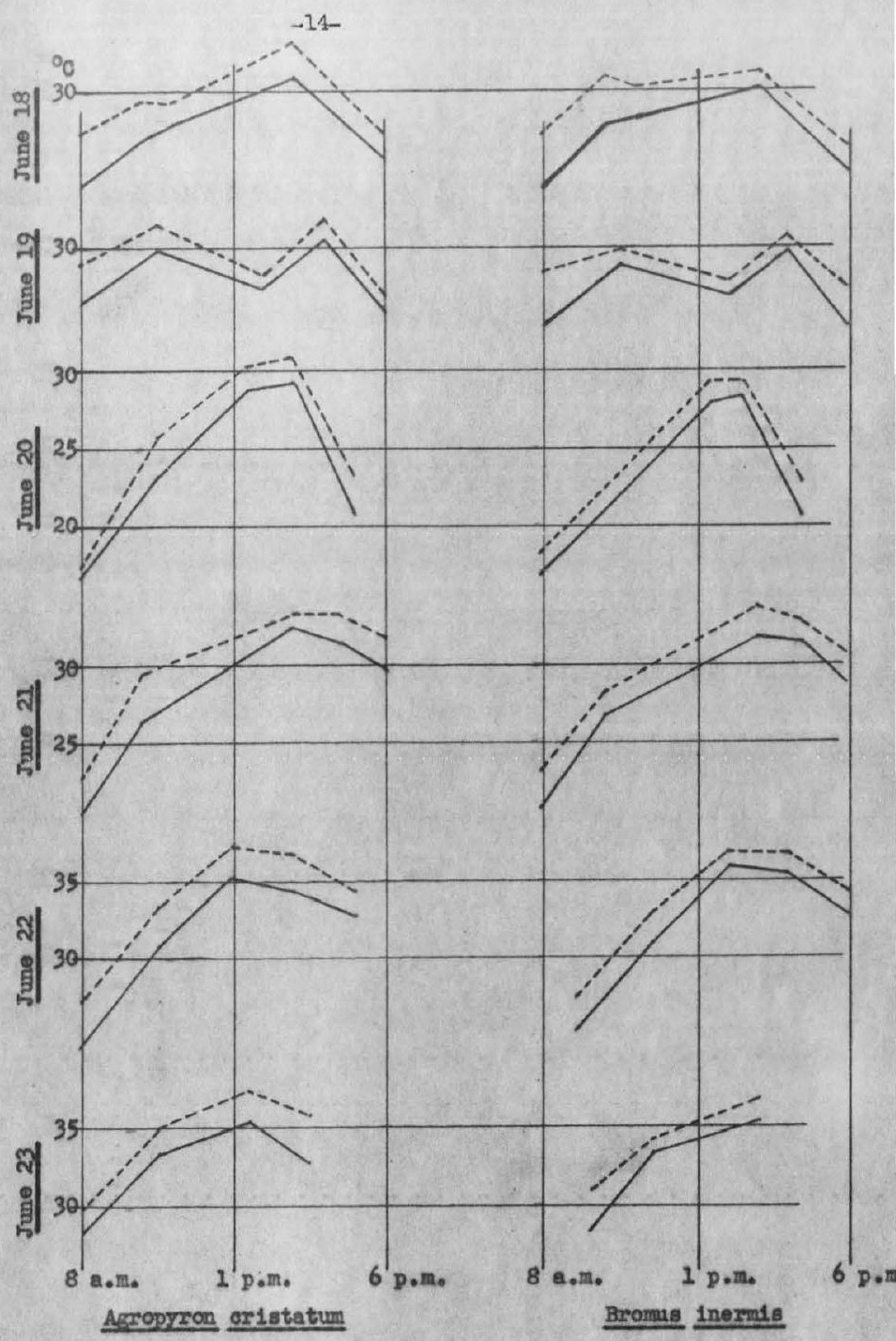

Figure 1. Alr temperatures inside (dotted 1ines) and outside the 1solation begs (solid Iines) for Agropyxon criatatum and Bromus 1narnds for a period of six days during anthesis. 
Improbable that a difference in temperature of this magnitude would be responsible for the very significant reduction in seeds produced under begs. It is probable, however, that Iight, humidity, air composition or other factors which the beg might influence, or a conbination of any of these might contribute to the effect noted. As mentioned above, it is also probable that part of this effect relates to inadequate pollination, even when exposures were made for one hour during anthesis on each of 5 sucessive pollen shedding deys.

The effect of time of treatment on seed production. One genotype of smooth bromegrass was selected to recelve treatments at hourly intervals throughout the day from 6:00 A. $\mathrm{L}$. to 6:00 P.II. Treatments were made at $45^{\circ}, 46^{\circ}$ and $47^{\circ} \mathrm{C}$. At each temperature 16 panicles were treated eimultaneously and then separated Into 6 groups, for pollination by different methods.

These were as follows:

(1) Tro panicles bagged in association with two intact panteles of another genotype (untreated) which provided pollen.

(2) Sane as (1) but in addition a cotton plug was placed in the top of each bag to serve as a ventilator.

(3) Three panicles bagged and pollinated on five successive pollon shedding days by introducing strained pollen into the top of the isolation bag.

(4) Three panicles bagged and pollinated by suspending two panicles in early anthesis in the top of the isolation bag on each of 5 pollen shedding days. 
(5) Three panicles were bagged but the bags were renoved for one hour during anthesis on each of 5 successive pollen shedding days.

(6) Three panicles left unbagged for natural open pollination.

Results from the first 5 groups, in which bags were in volved, are presented in table 4. The data represent means for the three treatment temperatures. It is evident that seed production is very 10w. The data suggest injury to the stigmas since 4 of the 5 methods averaged out approximately equal in efficiency. Examination of the means of different treatment intervals reveals a very pronounced dally cycle, many more seeds resulted from the treatments made during the wamer part of the day, than during the cooler part.

The data for the 6th method of pollination Listed above are presented in table 5. Approxinately half as many seeds were produced by open pollination of panicles treated at $47^{\circ}$ as by those treeted at $46^{\circ} \mathrm{C}$. I.ikewise only half as many seeds were produced following treatzent at $46^{\circ}$ as at $45^{\circ} \mathrm{c}$. Since the only differential was the treatment temperature, it appears to be a reasonable conclusion that at the higher temperatures an increasing amount of injury was suffered by the sttgmas. The means for time-of-treatment classes point clearly to the daily cycle which characterized the data presented in table 4 for bagged plants. It is evident that this oycle is not an effect of the bag. It is also evident that the cycle is most elearly 
Table 4. Effect of time of treatment on seed produetion by five methods of cross pollination in a self-sterile genotype of smooth bronegrass. Figures are seeds per 100 spikelets. leans of treatment at $45^{\circ}$, $46^{\circ}$ and $47^{\circ}$ C. $(43,930$ spikelets rent to make up table, each value averaged 1351$)$.

\begin{tabular}{|c|c|c|c|c|c|c|c|c|}
\hline \multirow[b]{2}{*}{ Treatment } & \multicolumn{7}{|c|}{ Time of treatzent } & \multirow{2}{*}{$\begin{array}{l}\text { Iean for each } \\
\text { cross pollinstion } \\
\text { method }\end{array}$} \\
\hline & \multicolumn{3}{|c|}{ A.116. } & \multicolumn{3}{|c|}{ P.14. } & $3:$ & \\
\hline A X B Bagged together & -2 & 0 & 5.8 & 6.7 & 3.0 & 0 & 0 & 1.88 \\
\hline $\begin{array}{c}\text { A X B (cotton plug) Bagged } \\
\text { together }\end{array}$ & .2 & 1.0 & 2.2 & 2.4 & 3.1 & 8.3 & 0 & 1.76 \\
\hline $\begin{array}{l}\text { A Selfed plus pollen } \\
5 \text { days }\end{array}$ & .0 & 2.3 & 4.4 & 2.5 & $\$ .6$ & 2.6 & 0 & 2.21 \\
\hline $\begin{array}{l}\text { Selfed plus severed } \\
\text { stens } 5 \text { days }\end{array}$ & .2 & .2 & 1.1 & .9 & .4 & 0 & 0 & .38 \\
\hline $\begin{array}{l}\text { Selfed plus } 1 \text { houx } \\
\text { exposure } 5 \text { daya }\end{array}$ & .2 & 1.0 & 8.7 & .3 & 1.5 & 1.9 & .1 & 2.93 \\
\hline AII methods two-hour neans & .24 & .88 & 3,94 & 2.56 & 2.28 & 1.56 & .02 & \\
\hline
\end{tabular}

* Actual values obtained from panicles trested at 6:00 P.H. have been doubled in order to make this column more comparable to the others. 
Table 5. Seeds produced per 100 spikelets of a self-sterile genotype of smooth bromegrass. The plants were emasculated at hourly intervals throughout the day but renafned unbagged. Ireatients were efther $45^{\circ}$ $46^{\circ}$ or $47^{\circ}$ G. for an interval of 5 minutes. $(7,545$ spikelets went to aake up table, each value averaged 255-572).

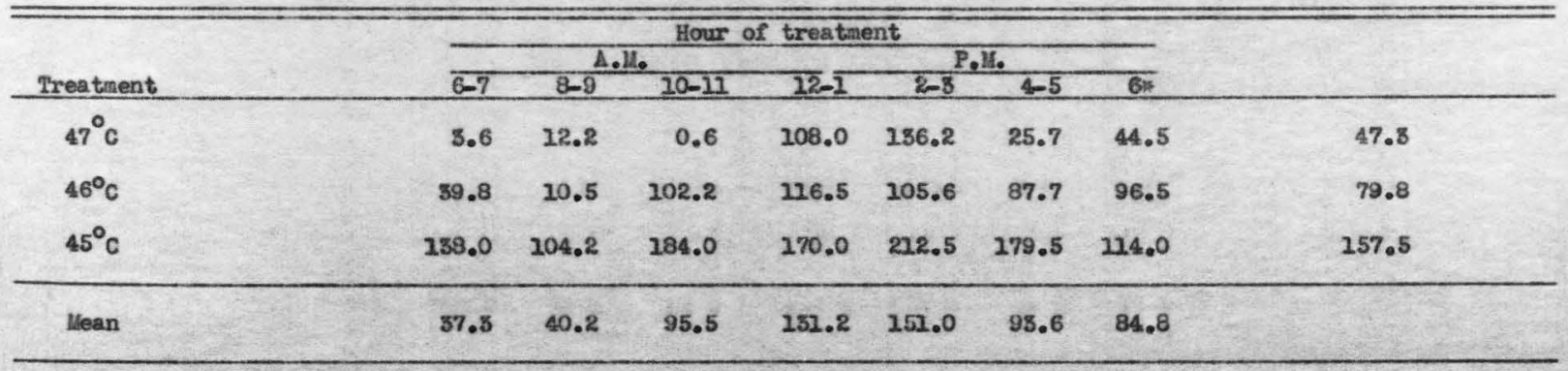

* Actual values obtained froa panicles treated at 6:00 P.u. have been doubled in order to make this column more compurable to the others. 
expressed at the higher treatment teraperatures. Table 6 presents the data of table 4 rearranged according to treatnent tenperatures. The striking feature of these data is the relationship of treatment temperature to the range in time of day through which treatinent led to relatively good seed sets. Relatively high seed yields were obtained from trentments at $47^{\circ} \mathrm{C}$. only when these treatinents were made in mid-day (12 noon to 1:00 P.M.). At $46^{\circ} \mathrm{C}$. relatively high seed yields were obtalned when treatinents were made between 10:00 A.M. and $3: 00$ P.M. while at $45^{\circ} \mathrm{C}$. this time range was extended from 8,00 A. if. to $5: 00$ P. I. Although the data do not so indicate, it is suspected that emasculation at $45^{\circ} \mathrm{C}$. may not have been highly effective at mid-day. In a broad sense these conclusions drawn fron table 6 are born out by the data presented in table 5. 
Table 6. Seeds produced per 100 splkelets in a self-sterle genotype of suooth bromegrass by cross pollination folloring enasculation at hourly intervals throughout the day. Fach value in the table is a mean of 5 methods of cross pollination. 43,950 spikelets went to make up table, each value averaged 2252.

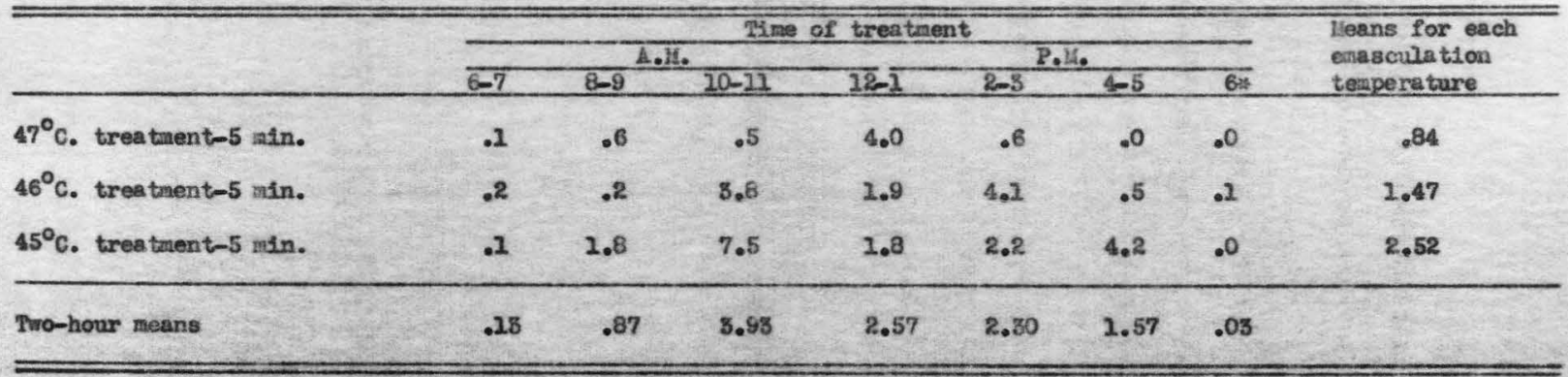

* Actual values obtained from panicles traated at 6,00 P.1. havo been doubled in order to make this column more comparable to the others. 


\section{JISCUSSION}

Domingo (2) obtained evidence that smooth bromegrass (B. inermis) could be almost conpletely emasculated by treatment of panicles with hot water. The success of erasculation was deterained by the number of seeds produced under begz by relatively selffertile genotypes following treatraent, in contrast to seeds produced by sinilarly treated panicles which were not bagged but remained exposed to open pollination. On this basi.s there appeared good evidence for a differential in the thermal death points of the male and fenale ganetoplytites of $2^{\circ}$ or $8^{\circ} \mathrm{C}$, He also obtained fairly satisfectory quantities of seed in his studies of bulk polifination made on untreated (self-ster1le) panicles. However, the results were disappointing when attempts were made to apply brik pollination technic to heat emasculated pantcles. It was clearly evident that trestment had been too severe. (AII treatments preceeding blalk polzination were at $47^{\circ} \mathrm{G}_{0}$ ).

In the present study all controlled pollination nethods were applled to trested inflorescences. The date presented in table I reveal sigmifloant increases in seed production, and aleariy denonstrate that a diffarential exists, but seed production is far below that of similarly treated but unbagged in norescences (table 2). This may be interpreted in el ther of 2 ways, (1) all methods of controlled pollination were inefflcient, or (2) the bag has a sterilising effect. Critical evidence $1 \mathrm{~s}$ 
not at hand but the second interpretation is favored by the mriter, because of the very strong evidence presented in table 2 when continuous exposure is conpared with 5 dally exposures of one hour duration during anthesis. It appears very inprobsble that the 5 daily exposures failed to provide ample opportunity for polzination. This view accepted, the disparity must be charged largely agalnat the isolation bag. However, this type of isolation bag has been used at this station for 5 years in inbreeding studies. Hany highly solf-fertile plants have been detected by its use. The bag alone, therefore, certainly does not sterlilse the plants. Conclusive evidence is presented that temperatures within the bags are approxdmately $2^{\circ} \mathrm{C}$. higher than those outside the bags. In vi.er of the much greater daliy variations this difference is not considered highly important. AII the data thus far avajlable can be harnonized if it is postrlated that an unfavorable interaction results from the bagging of troeted inforescences. This interaction appears to operate at tenperatures lowrer than those essential to emasculation as evidenced by the lou seed yields obtained by the various pollination methods (table 1) following enasculation at $45^{\circ} \mathrm{C}$. Clear-cut evidence is presented in tables 4, 5 and 6 to denonstrate the operation of a daily cycle in the reaction of the plant toward the emasculation treatnent. It is clear that a given terperature has a nore severe effect on the plant in the early porning and late afternoon than at rid-day but no explanation for the observed condition is at hand. 
AIthough new difficulties have been brought to light the present study adds welght to the belief that bulk hybridization can be realized because data are presented supporting the basic requirement of the method, namely the existence of a differential In the therral death points of male and fenele ganetophytes. 


\section{Sunakg}

Bvidence is presented supporting the findings of other Investigators that there is a dirferential in the thenal death points of nale and feniale gavietophytes. The dsfferential is best denonstrated by hot water treatzent at $47^{\circ} \mathrm{C}$. for five minutes just prior to nornal anthesis.

Hot water emasculation at tenperatures of $45^{\circ}, 46^{\circ}$, and $47^{\circ}$ C. at I hour intervals from 6:00 A. $\mathrm{H}_{0}$ to 6:00 P.il. revealed that treatments at mid-day were less injurious to the plant than treatments in the early norning or late afternoon. A treataient of $45^{\circ} \mathrm{C}$. at $6,00 \mathrm{~h}$. tion as a trestaient of $47^{\circ}$ C. at noon.

Five methods of controlled pollination were investigated. These methods are:

(1) Selfing.

(2) Bagged, but having strained pollen introduced into the bag on flive days favorabie for atmospheric pollen.

(3) Bagged, but having severed pollen bearing inflorescences introduced into the bag on IIve successive pollen shedding days.

(4) Bagged, with severed pollen bearing inflorescences standing in water and inserted in the bag at the beginning of anthesis.

(5) Bagged, but in association with intact panteles of another genotype (untreated) which provided pollen.

Natural poilination consisted of:

(1) Treated panicles exposed to wind borne pollen at hourly intervals on each of five days during antheais. 
(2) Panicles left unbagged and alloired free access to atzospherle pollen.

None of the methods of controlled pollinations gave satisfactory seed yields. The low seed ylelds obtained were the result of sone factor or combination of factors other than emasculation treatment, since sindlarly treated Inflorescences exposed to continuous pollination (no bagged) gave very satisfactory seed ylelds. S1milarly treated panicles exposed for one hour on 5 successive pollen shedding days produced no more seed than controlled pollination, methods $2,8,4$ and 5 . 


\section{LITERA TURE GITED}

1. Coulter, Herle C. A corn-poluinator. Bot. Oaz., 68:63-64. 1919.

2. Domingo, Wayne E. Bulk emasculation and pollination of snooth bromegress (Bromus inerris). Jour. Amer. Soc. Agran. 53:998-1002. 1941.

5. Jodon, N. B. Bxperinents on artiffeial hybridization of 2ice. Jour. Aner. Soc. Agron., 30:294-505. 2938.

4. Stephens, J. C., and Quinby, J. R. Bulk emasculation of sorghum flowers. Jour. Amer. Soc. Agron,, 25:238-234. 1933.

5. Suneson, Colt A. Brasculation of wheat by chlizing. Jour. Amer. Soc. Agron., 29:247-249. 1957.

6. Webber, Herbert J. Xenis, or the imnediate effect of polien, in maize. V.S.D.A. Div. Veg. Phys. and Path. Bul. 22. 1900. 